\title{
Clinical diagnosis: When is it not inflammatory bowel disease?
}

CN WILLIAMS, MD, FRCPC, FACP, FACG

\begin{abstract}
Three situations mimic ulcerative colitis. First, in homosexual men, acute self-limited colitis due to campylobacter, salmonella or shigella is seen. Neisseria gonorrhea, herpes simplex, Chlamydia trachomatis and Entamoeba histolytica or a combination of these may also be present. The second setting is that of acquired immune deficiency syndrome (AIDS), where opportunistic infections, cytomegalovirus, cryptosporidium, Salmonella typhimurium and Escherichia coli 0157:H7 may cause diagnostic difficulty. The third situation is when patients have recently returned from or are in an endemic area for infectious diarrhea. This particularly affects the elderly, where salmonella, E coli 0157:H7, shigellosis and, increasingly, pseudomembranous colitis secondary to cytotoxin from Clostridium difficile, occur. The differential diagnoses for Crohn's disease include such disparate conditions as solitary rectal ulcer in females, and ischemic change in the elderly, which usually involves the splenic flexure area of the colon, but may also involve the rectosigmoid area. When a mass is present in the right lower quadrant, the differential diagnosis also includes local abscess formation from a perforated appendix or foreign body, tuberculosis and carcinoma. In the immunocompromised patient, Mycobacterium avium-intracellulare infection and Kaposi's sarcoma may mimic inflammatory bowel disease. Yersinia enterocolitica is becoming increasingly recognized as a cause of acute enteritis, predominantly in the ileum, often with coexistent mesenteric adenitis. Drugs may also cause diagnostic confusion. The one most recognized is antibiotic-associated pseudomembranous colitis. However, cleansing soapsuds, Fleet (Frosst) and bisacodyl enemas, methyldopa and Myochrysine (Rhône-Poulenc) may also cause colitis. Nonsteroidal anti-inflammatory agents may produce ileal ulceration and a clini$\mathrm{cal}$ and radiological picture resembling Crohn's disease. Potassium chloride also causes discrete ileal ulcers. Five case reports are presented to illustrate these diagnostic difficulties. Can J Gastroenterol 1990;4(7):341-346 (pour résumé, voir page 342)
\end{abstract}

Key Words: Differential diagnosis, Inflammatory bowel disease
$\mathrm{T}$ HE FIRST QUESTION TO BE ASKED when faced with a potential inflammatory bowel disease (IBD) patient is: Does the patient suffer from IBD? If so, is the disease ulcerative colitis or Crohn's disease? How active is the disease? Is it fulminant, severe, moderate, mild or inactive? What is the anatomical situation of the disease in the bowel? Is there a site-specific malfunction present? What is the general nutritional status of the patient? Are there intestinal complications? Are there extraintestinal complications? Is malignancy present or not? Does the duration of the disease require a surveillance program for the development of malignancy?

When ulcerative colitis is present the patient will present with rectal bleeding almost invariably with each and every bowel movement $(1-4)$ There may be urgency, tenesmus, diarrhea and abdominal cramps, often with no recognizable stool, especially with total colon involvement. Up to $30 \%$ of patients may have a constipated stool, particularly when rectal disease only is present. There may be associated fever and weight loss - all of these symptoms being present for at least six weeks. On sigmoidoscopy, the rectal mucosa is diffusely involved, and on biopsy, charac- 


\section{Diagnostic clinique: Quand ne s'agit-il pas d'une maladie inflammatoire de l'intestin?}

RESUME: Trois situations simulent la colite ulcéreuse. Premièrement, chez les patients homosexuels, on relève les colites spontanément résolutives aiguës attribuables à Campylobacter, à Salmonella et à Shigella. On peut également se trouver en présence d'une blennoragie à Neisseria, d'un herpès, d'une infection à Chlamydia trachomatis et à Entamoeba histolytica, ou d'une combinaison de ces affections. La deuxième situation est celle du syndrome d'immunodéficience acquise (SIDA) où les infections opportunistes à cytomégalovirus, à Cryptosporidium, à Salmonella typhimurium et à Escherichia coli 0157-H7 peuvent brouiller le diagnostic. La troisième situation implique les patients qui reviennent d'une voyage en zone endémique de diarrhée infectieuse, où qui résident dans une telle région les personnes âgées surtout, particulièrement exposées aux infections à Salmonella, à E coli $0157-\mathrm{H} 7$ et à Shigella et, en nombre croissant, à la colite pseudo-membraneuse secondaire à la cytotoxine provenant de Clostridium difficile. Le diagnostic différentiel de la maladie de Crohn couvre des affections diverses allant de l'ulcère solitaire du rectum chez la femme au changement ischémique chez la personne âgée, lequel implique habituellement l'angle gauche du côlon mais peut également inclure la région rectosigmoïdienne. Quand une masse est décelée dans le quadrant inférieur droit, le diagnostic différentiel peut également envisager la formation d'un abcès local résultant d'une perforation de l'appendice ou d'un corps étranger, la tuberculose ou un cancer. Chez le patient immunodéprimé, l'infection à Mycobacterium avium-intracellulare et le sarcome de Kaposi peuvent également mimiquer une maladie inflammatoire de l'intestin. De plus en plus, Yersinia enterocolitica est reconnu comme origine de l'entérite aiguë, surtout au niveau de l'iléon et souvent avec une adénite mésentérique coexistante. Les médicaments peuvent également brouiller les pistes diagnostiques. La colite pseudomembraneuse associée à l'antibiothérapie est l'affection la plus souvent décelée. La colite peut également être causée par les lavements à base de détersifs, Fleet (Frosst) et Bisacodyle, la méthyldopa et la myocrisine (Rhône-Poulenc). Les anti-inflammatoires non stéroïdiens peuvent provoquer une ulcération iléale et des radiologies évocatrices de la maladie de Crohn. Le chlorure de potassium peut aussi entraîner des ulcères discrets de l'iléon. Cinq cas sont rapportés pour illustrer ces problèmes diagnostiques.

\section{TABLE 1}

Differential diagnosis of proctitis

\begin{tabular}{lccccccc}
\hline $\begin{array}{l}\text { Type of } \\
\text { proctitis }\end{array}$ & $\begin{array}{c}\text { Acute } \\
\text { onset }\end{array}$ & $\begin{array}{c}\text { Bleed- } \\
\text { ing }\end{array}$ & $\begin{array}{c}\text { Rectal } \\
\text { pain }\end{array}$ & $\begin{array}{c}\text { Tenes- } \\
\text { mus }\end{array}$ & $\begin{array}{c}\text { Diarrhea Mucosal } \\
\text { friability }\end{array}$ \\
\hline Ulcerative & \pm & + & 0 & + & + & + & 0 \\
Crohn's & \pm & \pm & + & + & + & \pm & + \\
Campylobacter & + & + & 0 & + & + & + & 0 \\
Herpes simplex & + & \pm & + & + & \pm & 0 & + \\
Gonococcal & + & \pm & + & + & \pm & 0 & 0 \\
\hline
\end{tabular}

teristic histological changes are usually present. These include inflammatory change limited to the epithelial surface, with crypt abscess(es) and diffuse inflammatory infiltrate. The sites involved may be rectal alone, which is seen over half the time in patients with ulcerative colitis, affecting the left side alone, or there may be total colon involvement. Differential features for different types of proctitis are shown in Table 1.
In general, the main differential diagnosis in patients with ulcerative colitis is that of acute self-limiting colitis. The groups in which this most resembles ulcerative colitis are: homosexual men, human immunodeficiency virus (HIV) infection and the elderly (5).

In homosexual men, acute selflimiting colitis may be caused by single or multiple organisms. The most common organisms being campylobacter,
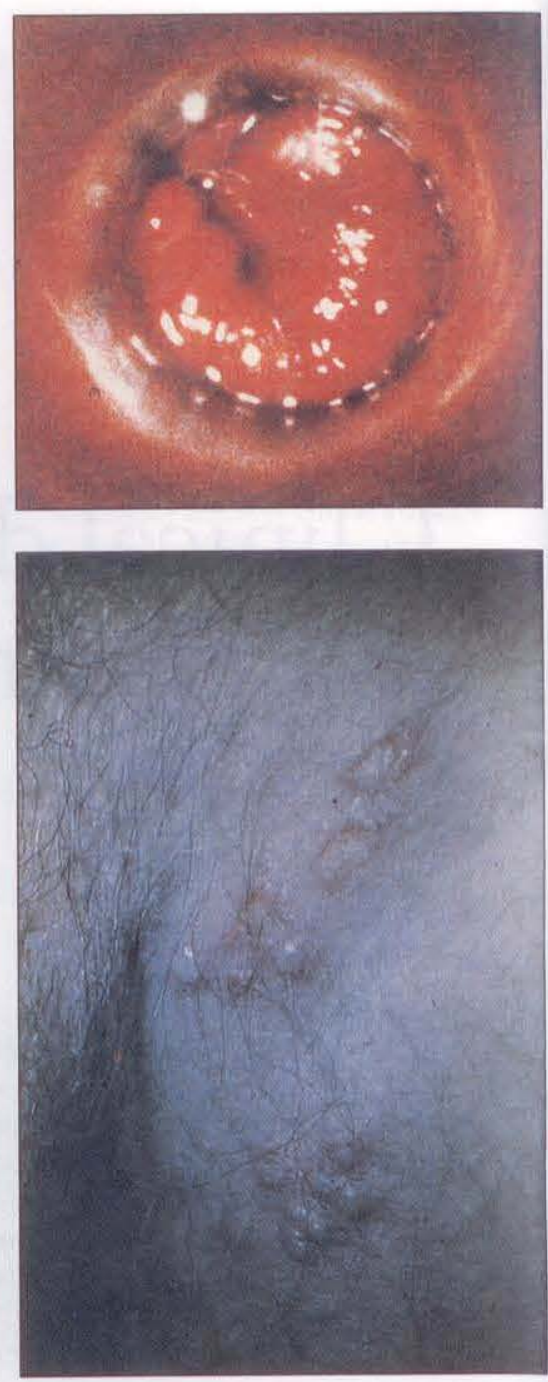

Figure 1) Top The sigmoidoscopic appearance of a single mucosal ulcer. Bottom Characteristic vesicles of herpes simplex infection

salmonella, shigella, Neisseria gonor. rhea, herpes simplex, chlamydia or Entamoeba histolytica. The sigmoidoscopic findings in a 30-year-old homosexual male, who presented with extreme rec. tal pain, tenesmus and rectal bleeding are shown in Figure 1. He had a perianal rash. In this instance, the considerations were gonococcal proctitis, foreign body injury, chlamydia or Treponema pallidum infection. How ever, the vesicles with surrounding red halo are classical for herpes simplex infection, and herpes simplex was iso. lated from biopsies taken from the characteristic rectal ulcer.

With HIV infection, conditions that give rise to difficulty include: cytomegalovirus colitis, colitis as. 


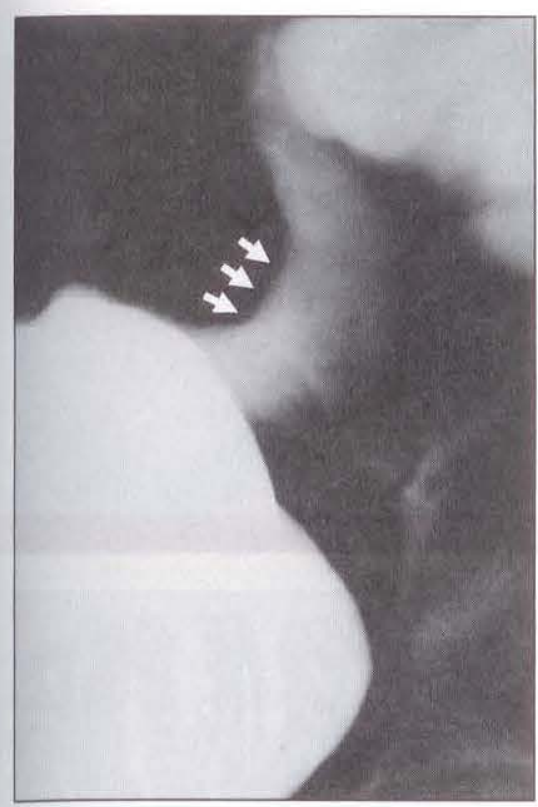

Figure 2) Barium enema showing excellent filling of the distal ileum. There are mucosal irregularities in keeping with ulceration (arrows)

sociated with cryptosporidium, Salmonella bifermentans, and the syndrome associated with Escherichia coli 0157:H7 (6). In this last situation, the stools are characteristically liquid, perfuse, but nonbioody for the first $24 \mathrm{~h}$, changing then to bloody. In ulcerative colitis, blood is present in each and every bowel movement from the first moment of onset of the illness. More recently, Kaposi's sarcoma, when situated in the rectum or left colon, may present with rectal bleeding and diarrhea, as indeed, will colitis associated with Mycobacterium avium-intracellulare.

As an example of this, a 45-year-old male presented with a one week history of abdominal pain and diarrhea without fever. Four days later, he had a massive rectal bleed. Abdominal $\mathrm{x}$-rays showed a dilated right colon. Subtotal colectomy was performed for fulminant colitis with impending toxic megacolon. His lover had died eight months earlier from acquired immune deficiency syndrome (AIDS). Sigmoidoscopy confirmed rectal involvement with diffuse change, with erythema, edema and no ulceration. The resected colon showed transmural disease, with linear longitudinal ulcers in the descending colon, the rectum being relatively spared. The patient eventually presented with Pneumocystis carinii pneumonia, and developed a positive HIV antibody test. Re-examination of the colon revealed no evidence for cytomegalovirus inflammatory change, and his titres were, at that time, negative. Cryptosporidium was not present, nor did he have Kaposi's sarcoma or M avium-intracellulare. Stool culture was negative for enteric pathogens. The patient was considered to have indeterminate colitis.

In the elderly, especially when they have visited areas where endemic infections are prevalent, differential diagnoses include: acute self-limiting colitis particularly with organisms such as salmonella, shigella and E coli 0157:H7. There is a special situation usually seen in association with broad-spectrum antibiotic ingestion, that of pseudomembranous colitis due to cytotoxin from Clostridium difficile. The characteristic endoscopic appearances are described elsewhere (7), as is the characteristic histological change (8).

Crohn's disease is a chronic IBD characterized by transmural inflammation, with a characteristic constellation of symptoms, depending on the site involved (9-12). There are characteristic radiological, endoscopic and surgical findings, often with characteristic granuloma formation on biopsy. The characteristic sites involved are: the distal ileum, the ileum plus colon, the colon, the rectum, perianal areas; less commonly the upper gastrointestinal tract and rarely skin are involved. There may be fistulas present from an infected site to an adjacent loop of bowel, an adjacent organ, such as the bladder or skin. Characteristically, when Crohn's disease presents with ileal involvement there may be an associated inflammatory mass in the right lower quadrant. The differential diagnosis of this includes: appendiceal abscess, foreign body abscess, carcinoma, lymphoma, tuberculosis or, more rarely, sarcoidosis and yersiniosis.

An illustration in this setting is the case of a 35-year-old man who presented with right lower quadrant pain, bloating, diarrhea and poor appetite. He was not anemic. He had right lower quadrant tenderness and a white count of $16,000 / \mathrm{mm}^{3}$. Radiological findings demonstrated what appeared to be mucosal irregularities in the terminal ileum consistent with Crohn's disease (Figure 2). He was given prednisone and sulphasalazine, but was unresponsive after three months because of continuing symptoms, mainly pain. A laparotomy was performed. In this particular case, an abscess was found in relation to a perforated diverticulum in the sigmoid colon, and in the centre of this abscess was a fish bone. There was no evidence of Crohn's disease affecting the bowel, with the characteristic surgical findings of 'creeping fat'.

A further example was a 57-year-old female who presented in February 1988 with malaise, vomiting, abdominal cramps and diarrhea. Bowel movements were three to four per day and disturbed her sleep. These attacks lasted $24 \mathrm{~h}$ and occurred every one to two weeks. By June 1988, her weight had diminished by about $3.5 \mathrm{~kg}$; upper and lower gastrointestinal tract contrast studies showed skip lesions in the ileum and colon (Figure 3).

The diagnosis of Crohn's disease was made, and symptoms improved on sulphasalazine. However, persistent nausea resulted in a further weight loss of $3.5 \mathrm{~kg}$. Prednisone was added and abolished her symptoms and she regained $2.7 \mathrm{~kg}$ in weight. In October 1988 , the patient was well with excellent energy, and had gained a further 3 $\mathrm{kg}$. Bowel movement was one formed motion per day. The prednisone dose was tapered and discontinued.

In December 1986, left lower quadrant pain occurred with constipation and the patient stayed off work. A $12 \times 8$ $\mathrm{cm}$ tender mass was palpable just below and to the left of the umbilicus. The white count was $12,000 / \mathrm{mm}^{3}$; hemoglobin $130 \mathrm{~g} / \mathrm{L}$; mean corpuscular volume $103 / \mathrm{fL}$; and platelets $20 \times 10^{9} / \mathrm{L}$. This illness settled quickly and the patient was discharged on prednisone and metronidazole.

In February 1987, she was admitted to hospital with further attacks of abdominal pain with associated distension and vomiting, and no bowel 

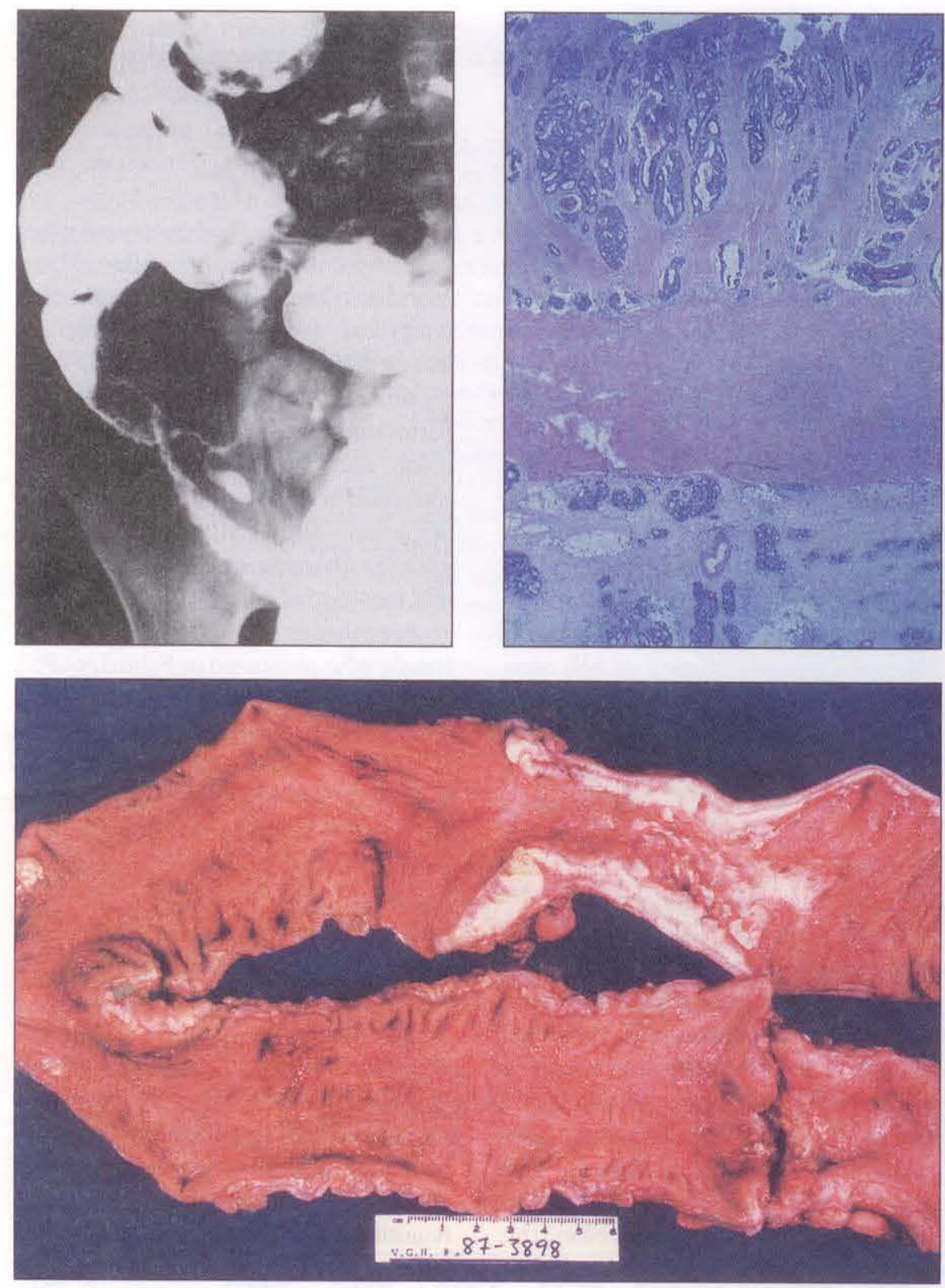

Figure 3) Top left Barium enema showing irregularity and narrowing of the ileum and colon in two skip lesions, compatible with the diagnosis of Crohn's disease. Bottom Resected specimen showing the skip lesions. Top right Adenocarcinoma infiltrating the full thickness of the colonic wall with lymphatic spread

movement for several days. Abdominal distension with left periumbilical tenderness and guarding was present. Hemoglobin was $155 \mathrm{~g} / \mathrm{L}$; white count $11,000 / \mathrm{mm}^{3}$; mean corpuscular volume $101 / \mathrm{fL}$; sedimentation rate of $31 \mathrm{~mm} / \mathrm{L}$; serum $B_{12}$ was $50 \mathrm{pg} / \mathrm{mL}$ (normal 150 to 600 ); serum albumin was $34 \mathrm{~g} / \mathrm{L}$ (normal 35 to 50 ). She was treated with intravenous fluids and nasogastric suction and symptoms regressed. Her white count fell to normal; however, bowel movement did not return and laparotomy was performed. The diag- nosis prior to laparotomy was Crohn's disease with ileocolitis, with probable abscess formation. It was thought that obstruction had supervened from Crohn's disease, with a small possibility of carcinomatous change or a foreign body-induced obstruction. At laparotomy, a lesion was found in the colon, with a secondary lesion in the ileum. These areas were resected, and histology revealed an adenocarcinoma infiltrating the bowel wall and spreading through the lymphatics (Figure 3 ).

Other situations mimicking Crohn's
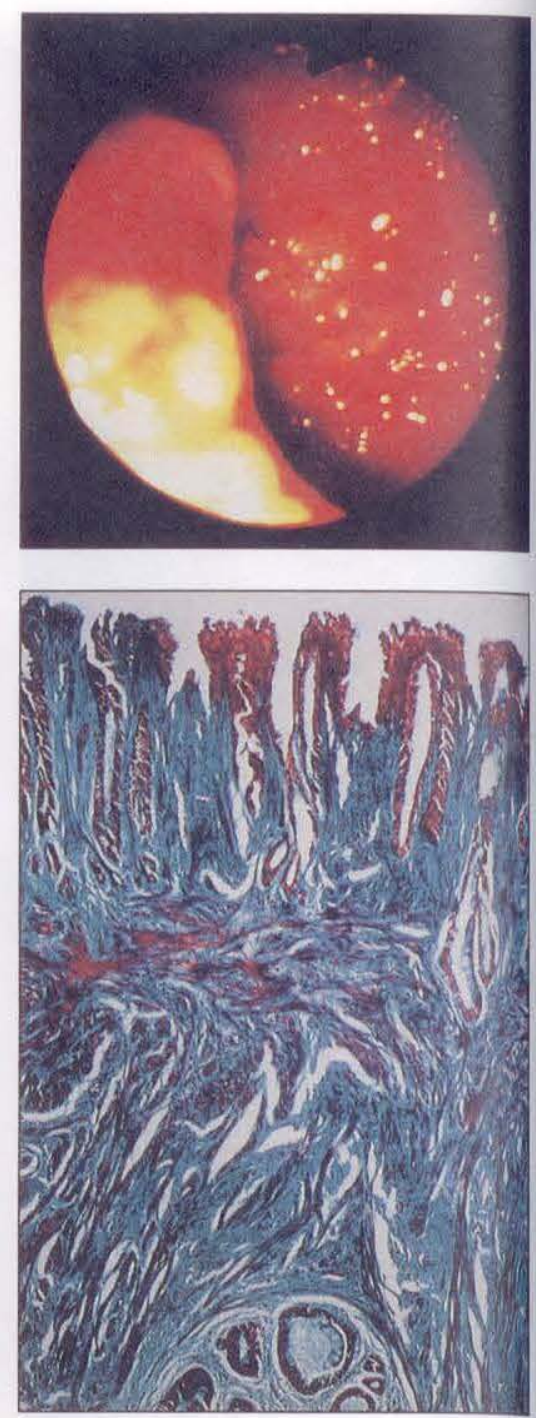

Figure 4) Top Sigmoidoscopic appearance of mucosal ulceration on both the anterior and posterior rectal wall approximately $10 \mathrm{~cm}$ from the anal margin. Bottom Masson's trichrome stain of the ulcers shown above. There is exces. sive fibrosis shown in green, the diagnostic fibromuscular proliferation in the muscularis mucosa. Note the pseudovillus configuration at the top and the displaced mucosal glands at the bottom of this photomicrograph

disease include: the spastic colon variety of the irritable bowel syndrome; ischemic colitis; diverticulitis (13); solitary rectal ulcer syndrome; carcinoma or lymphoma effecting the colon; amebiasis; and the increasing drug-induced forms of colitis or ileitis.

A 22 -year-old female presented with intermittent rectal bleeding and urgen. cy with a sense of incomplete evacuation. She had been taking oral contraceptives for several months. Fig. 
TABLE 2

Laboratory findings in a 61-year-old female with ischemic colitis

\begin{tabular}{lcc}
\hline Laboratory test (normal values) & Admission & Seven days later \\
\hline Hemoglobin $(115$ to $155 \mathrm{~g} / \mathrm{L})$ & 160 & 108 \\
Leukocyte count $\left(4.5\right.$ to $\left.10.5 \times 10^{\circ} / \mathrm{L}\right)$ & 21,000 & 33,000 \\
Platelet count $\left(150\right.$ to $\left.350 \times 10^{9} / \mathrm{L}\right)$ & 294,000 & 37,000 \\
Erythrocyte sedimentation rate & 4 & 5 \\
$(0$ to $7 \mathrm{~mm} / \mathrm{h})$ & 385 & 360 \\
Lactate dehydrogenase $(117$ to $259 \mathrm{iu} / \mathrm{L})$ & Schistocytes, & Same + \\
Blood smear & fragments & spherocytes \\
Plasma hemoglobin $(0$ to $50 \mathrm{mg} / \mathrm{L})$ & 142 & 250 \\
Haptoglobin $(0.2$ to $1.6 \mathrm{~g} / \mathrm{L})$ & 0.05 & 0.05
\end{tabular}

ure 4 shows the lesion documented at sigmoidoscopy and the characteristic histological change from solitary rectal ulcer syndrome. Note that multiple ulcers are often present in this syndrome. Nogranulomas were present. The ulcer is thought to be due to ischemia. The sense of incomplete evacuation and the demonstration of mucosal prolapse on defecography are often helpful diagnostic pointers.

Ischemic colitis often causes diagnostic confusion in the elderly (5). There may be an underlying condition associated with an ischemic colitis presentation. A 61-year-old female presented with a one day history of malaise, nausea, anorexia and abdominal cramps and diarrhea. The stool was liquid, brown, small in volume and, after $24 \mathrm{~h}$, became bloody with each bowel movement. There was no fever, chills or rash. Admission laboratory findings are shown in Table 2. Sigmoidoscopy revealed a diffusely reddened, swollen, nonfriable mucosa, and biopsy was nonspecific. Acute selflimiting colitis was considered, specifically $E$ coli $0157: H 7$ infection, because white cells were frequent in the stool smear and because of the delayed hematochezia. E coli 0157:H7 and shigella, salmonella, yersinia, campylobacter, aeromonas and $\mathrm{C}$ difficile cytotoxin were not found in the stool. An indium scan showed increased uptake in the descending colon.

The clues for diagnosis were present on a peripheral blood smear at admission, suggestive of underlying hemolysis. The subsequent course showed profound thrombocytopenia with early hemolysis. Persistent thrombocyto- penia, unresponsive to platelet transfusion, plasmapheresis or corticosteroids, developed. There was progressive renal involvement with proteinuria and red cells present in the urine. The patient became dysarthric, developed a left facial paralysis and died from respiratory failure. Widespread involvement with thrombotic thrombocytopenic purpura was confirmed at autopsy.

latrogenic disorders that can mimic IBD include: antibiotic-associated pseudomembranous colitis, colitis resulting from the use of soapsuds, Fleet enema (sodium phosphate; Merck Frosst), bisacodyl enemas (6) and a colitis described secondary to Myochrysine (sodium aurothiomalate; Rhône-Poulenc) therapy for rheumatoid arthritis (personal communication). Acute colitis has also recently been described secondary to methyldopa administration (14). Proctitis has also been described in association with contraceptive pill use, and recently there has been much interest concerning nonsteroidal anti-inflammatory drug-induced small bowel lesions (15). These lesions may mimic Crohn's disease of the ileum, and may mimic the ulceration seen with potassium chloride. In addition, there are specific lesions described with nonsteroidal anti-inflammatory drugs, ie, multiple diaphragmatic strictures.

When IBD is present, in the great majority of situations the specific diagnosis can be made readily by the constellation of symptoms and signs, and sigmoidoscopy with biopsy, or by the additional use of colonoscopy, indium scans or careful contrast studies of the gastrointestinal tract. In a small percentage of patients, probably less than $5 \%$, it may not be possible to make a specific diagnosis initially, a condition called 'indeterminate colitis'. The diag. nosis usually becomes apparent with time. The usual difficulty is with patients diagnosed as having ulcerative colitis that actually have Crohn's disease affecting the colon, rather than the reverse situation. A careful drug history, attention to detail of recent travel where exposure to endemic infections may have occurred, and the appropriate bacteriological investigations will detect patients who have acute self-limiting colitis. If the anticipated therapeutic response is not seen when the patient is considered to have Crohn's disease, laparotomy may be necessary to make a specific, often unusual, diagnosis. This is particularly true for the more obscure differential diagnoses related to foreign body, carcinoma or lymphoma.

\section{REFERENCES}

1. Cello JP. Ulcerative colitis. In: Sleisenger MH, Fordtran JS, eds. Gastrointestinal Disease Pathophysiology, Diagnosis and Management, Vol 2, 3rd edn. Philadelphia: WB Saunders Company, 1983:1126.

2. Singleton JW. Clinical features, course and laboratory findings in ulcerative colitis. In: Kirsner JB, Shorter RG, eds. Inflammatory Bowel Disease, 3rd edn. Philadelphia: Lea and Febiger, 1988:168.

3. Farmer RG. Medical aspects of inflammatory bowel disease. In: Farmer RG, Acktar E, Flesher B, ed. Clinical Gastroenterology. New York: Raven Press, 1983:347.

4. Farmer RG. Ulcerative proctitis, tractable or intractable. In: Barkin JS, Rogers AI, eds. Difficult Decisions in Digestive Disease. Chicago: Year Book Medical Publishers, 1989:370.

5. Jagiella V, Schuman BM, Tedesco FJ. Infectious colitis, what is an effective approach? In: Barkin JS, Rogers AI, eds. Difficult Decisions in Digestive Diseases. Chicago: Year Book Medical Publishers, 1989:451.

6. Freeman HS. Definition of inflammatory bowel disease. Inflammatory Bowel Disease, Vol 1. Boca Raton: CRC Press, 1989:4.

7. Salena BJ, Hunt RH. Applications and pitfalls of endoscopy in inflammatory bowel disease. Can J Gastroenterol 1990;4:324-30. 
8. Malatjalian DA. Pitfalls in the histological diagnosis of inflammatory bowel disease on colorectal biopsies. Can J Gastroenterol 1990:4:336-340.

9. Rhodes J, Harries AD, Mayberry JF, Dew MJ. Clinical features of Crohn's disease. In: Misiewicz JJ, Pounder RE, Venables CW, eds. Diseases of the Gut and Pancreas. Oxford: Blackwell Scientific Publications, 1987:771.

10. Donaldson RM Jr. Crohn's disease. In: Sleisenger MH, Fordtran JS, eds. Gastrointestinal Disease Pathophysiology, Diagnosis and Management, Vol
2, 3rd edn. Philadelphia: WB Saunders, 1983:1099.

11. Law DH. Intractibility in Crohn's disease. In: Griffen WO, Mandelstam P, eds. Selected Gastrointestinal Disorders; Intractibility and its Management. Baltimore: Williams and Wilkins, 1987:105.

12. Wise L, Strauss RJ, Ballinger WF. The role of surgery in Crohn's disease. In: Grifen WO, Mandelstam P, eds. Selected Gastrointestinal Disorders; Intractibility and its Management. Baltimore: Williams and Wilkins, 1987:119.
13. Nugent FW, Kolack PF. Differential diagnosis of chronic ulcerative colitis and Crohn's disease of the colon. In: Kirsner JB, Shorter RG, eds. Inflammatory Bowel Disease, 3rd edn. Philadelphia: Lea and Febiger, 1988:185.

14. Troster M, Sullivan SN. Acute colitis due to methyldopa. Can ] Gastroenterol 1989;3:182-4.

15. Bjarnason 1. NSAID-induced small intestinal inflammation in man. In: Pounder R, ed. Recent Advances in Gastroenterology. Edinburgh: Churchill Livingstone, 1988:25. 


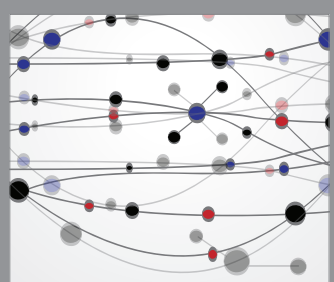

The Scientific World Journal
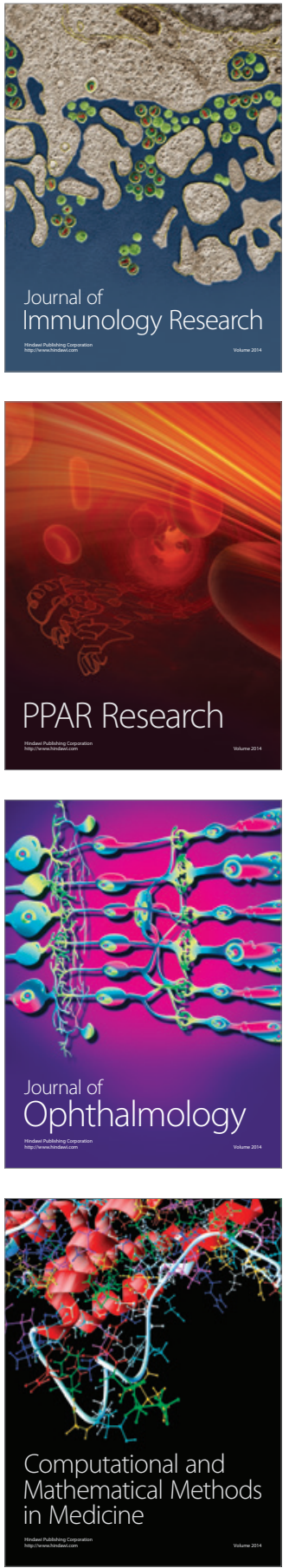

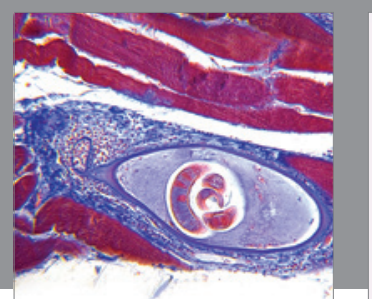

Gastroenterology Research and Practice

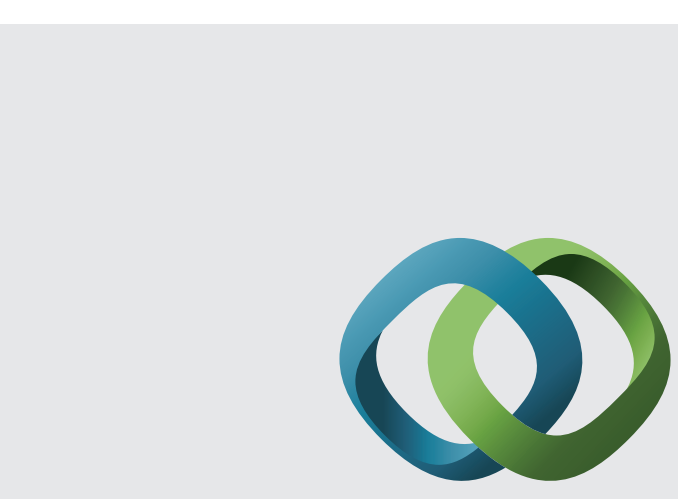

\section{Hindawi}

Submit your manuscripts at

http://www.hindawi.com
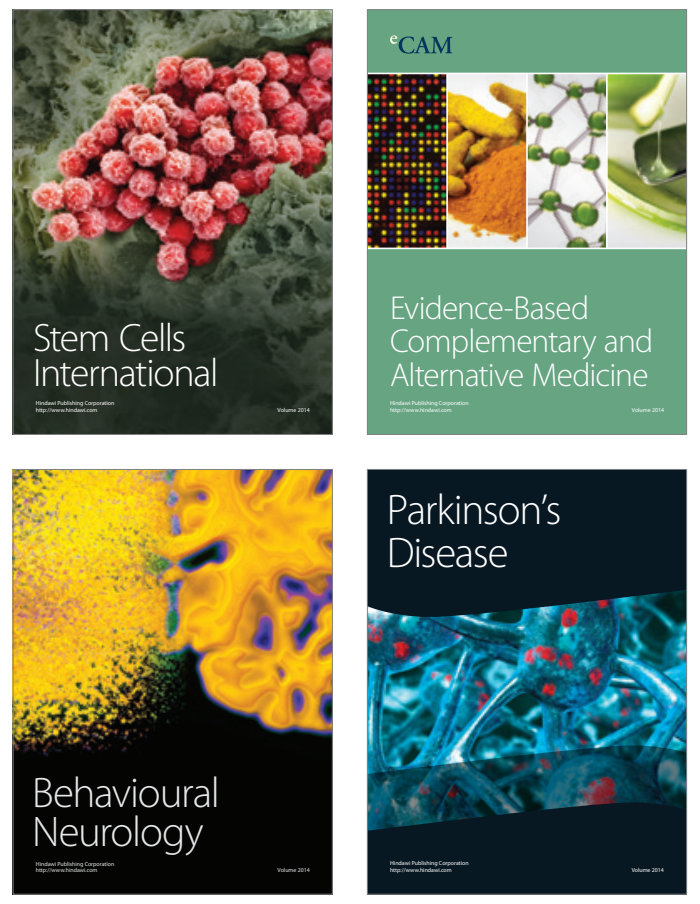
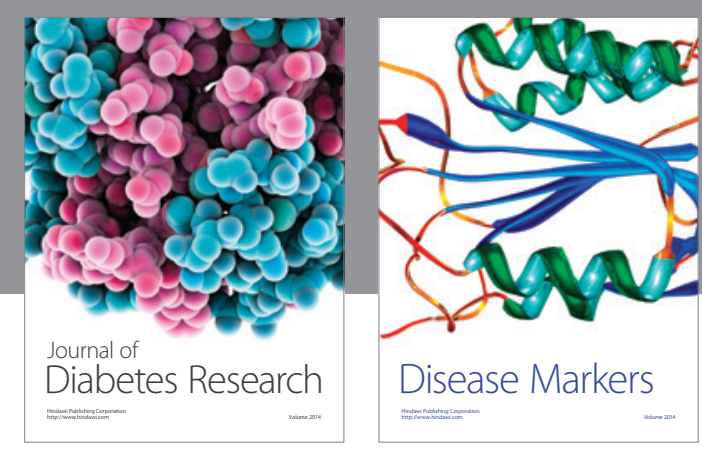

Disease Markers
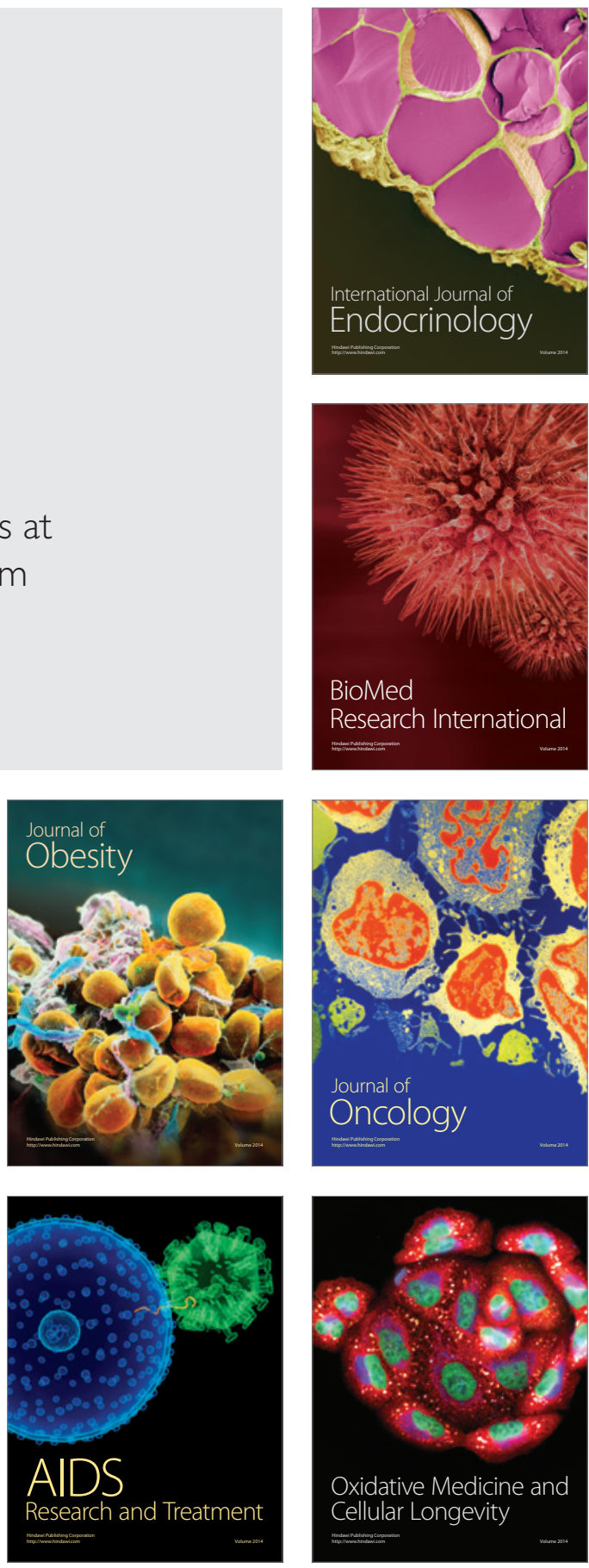